\title{
Hydrothermal synthesis, structure and thermal stability of diamine templated layered uranyl-vanadates
}

\author{
M. Rivenet ${ }^{1}$, N. Vigier, P. Roussel, F. Abraham \\ Unité de Catalyse et de Chimie du Solide, Equipe Chimie du Solide, UCCS UMR CNRS 8181, USTL, \\ ENSC-B.P. 90108, 59652 Villeneuve d'Ascq Cedex, France.
}

Murielle.rivenet@ensc-lille.fr

Running Title :

\section{Diamine templated layered uranyl-vanadates.}

Figure for table contents

Keywords:

Diamine uranyl vanadates, Crystal structure,

Hydrothermal synthesis, layered structure

\footnotetext{
${ }^{1}$ To whom correspondence should be addressed; E-mail: Murielle.rivenet@ensc-lille.fr
} 


\title{
Hydrothermal synthesis, structure and thermal stability of diamine templated layered uranyl-vanadates
}

\author{
M. Rivenet, N. Vigier, P. Roussel, F. Abraham
}

Unité de Catalyse et de Chimie du Solide, Equipe Chimie du Solide, UCCS UMR CNRS 8181, USTL, ENSCL-B.P. 90108, 59652 Villeneuve d'Ascq Cedex, France.

\section{Abstract \\ Introduction}

The solid state chemistry of uranyl - containing inorganic compounds is very rich in diversity. In particular, the association of hexavalent uranium polyhedra and oxoanion such as silicate, phosphate, vanadate, molybdate, tungstate. . constitutes a true building set leading to structures with varied architectures and dimensionalities, although there is a tendency to form layered structure due to the presence of uranyl bonds that preclude the connection in a third dimension. The basic building units are the uranium polyhedron, which can be hexagonal bipyramid, pentagonal bipyramid or distorted octahedron and the oxoanion which can be tetrahedron, square bipyramid or octahedron. The structural arrangement depends on many factors, such as the U/oxoanion ratio, that influence the degree of polymerization between the uranium polyhedra which can be connected directly through equatorial oxygen atoms or through the oxo - anions polyhedra.

Our group of research mainly focuses on the solid state chemistry of uranyl-vanadates compounds [1-7]. In almost the studied oxides, the association of uranyl polyhedra through vanadate oxoanions leads to bi-dimensional anionic sheets with contercation in the interlayer space. However in a recent paper, we described a novel three-dimensional open - framework uranyl-vanadate obtained using small monovalent ions (Li and $\mathrm{Na}$ ) [8].

Owing to the potential applications for this type of materials (radioactive waste management, uranium geochemistry, ion-exchange and catalysis), a series of reactions was conducted in order to obtain new open-framework uranyl-vanadates. One approach for designing novel layered and microporous uranium-bearing materials is to exert influence over structural features through the introduction of templating agents. Amines have historically been used as charge balancing, space filling and templating agents in various systems including molybdate [9-13], phosphate [14-18], phosphite [19], selenate [20], selenite [21], 
arsenate [17] sulfate [22-31] and fluoride containing compounds [18, 31-39] but organically templated uranyl-vanadates systems remained unexplored so far.

The materials described in the present paper were obtained by means of reactions of inorganic species and U/V ratio equal 1 with excess of amines under hydrothermal conditions. Two linear diamines of different length (1,2-ethylenediamine (en), 1,3-diaminopropane (dap)) and three cyclical diamines based upon piperazine (piperazine (pip), 1-methylpiperazine (mpip) and 1,4-diazabicyclo[2,2,2]octane (dabco)) were employed so as to vary the structures of the organic templates from a reaction to an other. Syntheses led to six new layered uranylvanadates which crystal structure and thermal behavior are reported herein.

\section{Experimental}

Synthesis

Uranyl nitrate $\left(\mathrm{UO}_{2}\left(\mathrm{NO}_{3}\right)_{2} \cdot 6 \mathrm{H}_{2} \mathrm{O}\right.$ - Prolabo, R.P. normapur), vanadium oxide $\left(\mathrm{V}_{2} \mathrm{O}_{5}\right.$ -Merck, Extra pur), concentrated chlorydric acid (Carlo Erba, 37\%, d=1.186) and amines (listed in Table 1) were used as received. For each synthesis the solutions were heated to $180^{\circ} \mathrm{C}$ in Teflon - lined $23 \mathrm{~mL}$ digestion bombs for a time varying from 1 to 30 days. The resulting powders were collected after cooling to ambient temperature, filtration and washing with deionized water. Reaction yields were not quantitatively determined.

$\left(\mathrm{NH}_{4}\right)_{2}\left[\left(\mathrm{UO}_{2}\right)_{2} \mathrm{~V}_{2} \mathrm{O}_{8}\right]$ (1) was synthesised using $\mathrm{UO}_{2}\left(\mathrm{NO}_{3}\right)_{2} \cdot 6 \mathrm{H}_{2} \mathrm{O}$ (301.3mg, $0.600 \mathrm{mmol}), \mathrm{V}_{2} \mathrm{O}_{5}$ (54.6mg, 0.300mmol), 1,2 - ethylenediamine $\left(\mathrm{C}_{2} \mathrm{H}_{8} \mathrm{~N}_{2}-90.2 \mathrm{mg}\right.$, $1.5 \mathrm{mmol})$ and deionized water $(15.1 \mathrm{~g}, 840 \mathrm{mmol})$. The mixture was heated at $180^{\circ} \mathrm{C}$ for 30 days. Absence of ammonium in the starting reactants indicates that the formation of ammonium ions must involve the in situ decomposition of ethylenediamine. Amines decomposition under hydrothermal conditions has previously been observed using pyridine [40], imidazole [41], and guanidinium amines [42-45]. It is worth noting that we were enable to obtain $\left(\mathrm{NH}_{4}\right)_{2}\left[\left(\mathrm{UO}_{2}\right)_{2} \mathrm{~V}_{2} \mathrm{O}_{8}\right]$ using a more direct source of ammonium cations.

$\left(\mathrm{H}_{2}\right.$ en $)\left[\left(\mathrm{UO}_{2}\right)_{2} \mathrm{~V}_{2} \mathrm{O}_{8}\right]$ (2) was prepared by hydrothermal reaction using a mixture of $\mathrm{UO}_{2}\left(\mathrm{NO}_{3}\right)_{2} \cdot 6 \mathrm{H}_{2} \mathrm{O}(301.3 \mathrm{mg}, 0.600 \mathrm{mmol}), \mathrm{V}_{2} \mathrm{O}_{5}(54.6 \mathrm{mg}, 0.300 \mathrm{mmol}), 1,2$ - ethylenediamine $\left(\mathrm{C}_{2} \mathrm{H}_{8} \mathrm{~N}_{2}-90.2 \mathrm{mg}, 1.5 \mathrm{mmol}\right)$ and deionized water $(15.1 \mathrm{~g}, 840 \mathrm{mmol})$ added with chlorydric acid ( $\mathrm{HCl}$ - 109.4mg, 3mmol). Time of synthesis was limited to 1 day in order to avoid the ethylenediamine decomposition. 
$\left(\mathrm{H}_{2}\right.$ dap $)\left[\left(\mathrm{UO}_{2}\right)_{2} \mathrm{~V}_{2} \mathrm{O}_{8}\right]$ (3), ( $\mathrm{H}_{2}$ pip) $\left[\left(\mathrm{UO}_{2}\right)_{2}\left(\mathrm{VO}_{4}\right)_{2}\right] \cdot 0.8 \mathrm{H}_{2} \mathrm{O}(\mathbf{4}),\left(\mathrm{H}_{2}\right.$ dmpip $)\left[\left(\mathrm{UO}_{2}\right)_{2} \mathrm{~V}_{2} \mathrm{O}_{8}\right]$ (5) and $\left(\mathrm{H}_{2}\right.$ dabco $)\left[\left(\mathrm{UO}_{2}\right)_{2}\left(\mathrm{VO}_{4}\right)_{2}\right](\mathbf{6})$ were obtained by conducting hydrothermal reactions at $180^{\circ} \mathrm{C}$ for 2 days using a mixture of $\mathrm{UO}_{2}\left(\mathrm{NO}_{3}\right)_{2} \cdot 6 \mathrm{H}_{2} \mathrm{O}(301.3 \mathrm{mg}, 0.600 \mathrm{mmol}), \mathrm{V}_{2} \mathrm{O}_{5}(54.6 \mathrm{mg}$, $0.300 \mathrm{mmol}), \mathrm{HCl}$ (109.4mg, 3mmol), deionized water $(15.1 \mathrm{~g}, 840 \mathrm{mmol})$ and, respectively, $\mathrm{C}_{3} \mathrm{H}_{10} \mathrm{~N}_{2}$ (111.2mg, 1.5mmol), $\mathrm{C}_{4} \mathrm{H}_{10} \mathrm{~N}_{2}$ (129.2mg, 1.5mmol), $\mathrm{C}_{5} \mathrm{H}_{12} \mathrm{~N}_{2}$ (150.3mg, 1.5mmol) and $\mathrm{C}_{6} \mathrm{H}_{12} \mathrm{~N}_{2}$ (168.3mg, 1.5mmol). During the synthesis of 5 under the hydrothermal conditions used, some 1-methylpiperazine (mpip) dismuted in 1,-dimethylpiperazine (dmpip) and piperazine (pip). The single crystals grew from mdpip when the presence of pip in the remaining solution was unambiguously proved by ${ }^{13} \mathrm{C}$ RMN.

The purity of the compounds was checked using X-ray powder diffraction. The X-ray powder patterns of the bulk samples can be fully indexed on the basis of the theoretical data calculated from the crystal structure results which evidences that pure phases are obtained. For compounds 1, 4, 5 and $\mathbf{6}$ crystals suitable for single crystal X-ray diffraction experiments have been isolated under optical microscope.

\section{Crystal structure determination}

Selected crystals of $\mathbf{1}, \mathbf{4}, \mathbf{5}$ and $\mathbf{6}$ were mounted on a glass fibber and aligned on a Bruker SMART CCD X-ray diffractometer. Intensities were collected at room temperature using $\operatorname{Mo} K \alpha(\lambda=0.71073 \AA)$ radiation selected by a graphite monochromator. The individual frames were measured using a $\omega$-scan technique. Omega rotation and acquisition time were fixed at $0.3^{\circ}$ and $20 \mathrm{~s}$ per frame, respectively. 1800 frames were collected in order to cover the full sphere. The Bruker program SAINT [46] was used for intensity data integration and correction for Lorentz, polarisation and background effects. After data processing, absorption corrections were performed using a semi-empirical method based on redundancy with the SADABS program [47]. Details of the data collection and refinement are given in Table 2.

The crystal structures were determined in the centrosymmetric space groups $P 2{ }_{1} / \mathrm{c}$ for 1, $P 2_{1} / \mathrm{b}$ for 5 and $C 2 / \mathrm{m}$ for both $\mathbf{4}$ and $\mathbf{6}$. A non-conventional setting was chosen for $\mathbf{5}$ so that the layers described hereafter are always in the (lllla 00 ) plane for $\mathbf{1}, \mathbf{5}, \mathbf{2}$ and $\mathbf{3}$ compounds. The heavy atoms $(\mathrm{U}, \mathrm{V})$ positions were established by direct methods using SIR97 program [48]. The oxygen, nitrogen and carbon atoms were localised from difference Fourier maps. The last cycles of refinement included atomic positions and anisotropic displacement 
parameters ADP for all atoms, excepted for partially occupied sites. Full-matrix least-squares structure refinements against $F$ were carried out using the JANA2000 program [49]. The atomic positional parameters and displacement parameters are given in Table 3 - compound 1, Table 4 - compound 5 and Table 5 - compounds 4 and 6. Some selected interatomic distances are reported in Table 6 - compounds $\mathbf{1}$ and $\mathbf{5}$, and Table 7 - compounds 4 and $\mathbf{6}$.

As no suitable crystals could be found for the $\mathbf{2}$ and $\mathbf{3}$ samples, crystal structure models were checked using X-ray powder diffraction data. The data were collected by means of a Huber G670 diffractometer using an asymmetric Guinier flat sample transmission geometry, equipped with a $2 \mathrm{D}$ detector (Image Plate) covering the $2 \theta$ range $\left[6-100^{\circ}\right]$. The $\left(\mathrm{H}_{2}\right.$ en $)\left[\left(\mathrm{UO}_{2}\right)_{2} \mathrm{~V}_{2} \mathrm{O}_{8}\right]$ and $\left(\mathrm{H}_{2}\right.$ dap $)\left[\left(\mathrm{UO}_{2}\right)_{2} \mathrm{~V}_{2} \mathrm{O}_{8}\right]$ samples were exposed, respectively, for one hour and half an hour to a monochromatized $\mathrm{Cu}-\mathrm{K} \alpha_{1}$ radiation obtained with a Germanium Johanson monochromator. For the ethylenediamine containing compound 2, the powder was dehydrated before measurement by heating the sample at $200^{\circ} \mathrm{C}$ for 1 hour. For the two compounds, structural models containing only the uranium - vanadium - oxygen sheets with distances constrained to the values calculated for the compounds $\mathbf{5}$ and $\mathbf{1}$, respectively are used and led to the results reported in Table 8.

For compound $\mathbf{2}$, the $\mathbf{b}$ and $\mathbf{c}$ parameters correspond to a carnotite - type layer, however the space group symmetry operations are incompatible with such a structure and as we could not find any structurally related compound, we attempted to solve the structure of compound 2 by ab initio procedures. The pattern decomposition option of the JANA2000 package [49] was used to extract corrected structure factors from a limited region of the diffractogram $\left(6<2 \theta<60^{\circ}\right)$. The pattern was fit without any structural model by refining the overall parameters: background, unit-cell parameters, zero-point error, peak shape (pseudoVoigt). The refinement converged to $\mathrm{Rwp}=\mathrm{xx}$ and $R p=\mathrm{xx} \%$. A total of $\mathrm{xxx}$ reflections were used as input to the direct-methods SIR97 program [48]. The positions of two U atoms were derived from this method. At this stage, the positions of the $\mathrm{V}$ atoms were deduced from a difference-Fourier map. Then, after refining the heavy atoms position and ADP, another difference-Fourier map revealed $\mathrm{O}$ atoms. At this stage we used soft constraints in the $\mathrm{U}-\mathrm{O}$ and $\mathrm{V}-\mathrm{O}$ bonds to avoid the structure blow up and to keep a reasonable geometry for the anionic sheets. Unfortunately, probably due to the high contrast between the $\mathrm{U}$ and $(\mathrm{C}-\mathrm{N}-$ $\mathrm{H})$ atoms of the amines, we were not able to see these last types of atomic species in a last difference-Fourier map. Without these "light" atoms and refining all positional parameters Rwp dropped to $1.80 \%$. Refining isotropic temperature factors freely resulted in some 
negative values. It is well known that temperature factors, for complex structures with heavy cations and medium resolution X-ray powder data, are quite unreliable. Hence, we decided to refine an overall isotropic temperature factor for $\mathrm{U}$ and $\mathrm{V}$ atoms and to fixe an overall temperature factor for the oxygen atoms. The refined positional parameters are reported in Table 9.

For the compound $\mathbf{3}$, the values of the cell parameters and the XRD pattern are very similar to those of uranyl vanadates of divalent A cations built from carnotite type layers. The space group deduced from the $\mathrm{X}$ - ray powder pattern indexation, $P$ mcn, is adopted for $\mathrm{A}=$ $\mathrm{Ca}$ [50], Mn, Co [51], Ni, Cd, Zn [52]. The precise lattice parameters were obtained from profile matching and, using the structural model of the divalent carnotite-type compounds layers, the reliability factors reported in Table 8 are obtained.

\section{High temperature $X$ - ray diffraction}

The high temperature X-ray powder diffraction patterns were recorded using a Guinier Lenné moving film camera. The samples were deposited on the sample holder (gold grid) using an ethanol slurry which yielded, upon evaporation, a regular layer of powdered compound. The high temperature X-ray diffraction patterns were recorded in the temperature range from 20 to $600^{\circ} \mathrm{C}$ with a heating rate in the range $\left[12-15^{\circ} \mathrm{h}^{-1}\right]$.

\section{Thermal analysis}

The thermal analyses were performed on a Setaram TG-DT 2-16.18 apparatus. Analyses were undertaken in air, in the temperature range from 20 to $600^{\circ} \mathrm{C}$, with a heating rate of $300^{\circ} \mathrm{h}^{-1}$, in platinum crucibles.

\section{Results}

\section{Cation coordination polyhedra}

For all the studied compounds, each of the uranium atom is strongly bonded to two oxygen atoms forming a nearly linear uranyl cation $\left(\mathrm{UO}_{2}\right)^{2+}$ with a $\mathrm{O}-\mathrm{U}-\mathrm{O}$ bond angle ranging from $178.6(4)$ to $179.5(3)^{\circ}$ and $\mathrm{U}-\mathrm{O}$ bond lengths ranging from $1.775(8)$ to $1.816(6)$ $\AA$ (average value of 1.79(2) $\AA$ ). The uranyl cations are coordinated by five oxygen atoms located in the equatorial plane which forms $\left[\mathrm{UO}_{7}\right]$ pentagonal bipyramids. The equatorial oxygen ligands show significant variations with $U-O$ distances ranging from 2.295(6) to $2.458(3) \AA$. However, the average value, 2.36(6) $\AA$, is in good agreement with the average 
bond length of 2.37(9) $\AA$ calculated for uranyl polyhedra of numerous well - refined structures [53].

The vanadium atoms of structures $\mathbf{1 , 2 , 3}$ and $\mathbf{5}$ are pentacoordinated by five oxygen atoms in a square pyramidal arrangement. Two $\mathrm{VO}_{5}$ square pyramids related by an inversion centre share an $\mathrm{O}-\mathrm{O}$ edge to form a $\mathrm{V}_{2} \mathrm{O}_{8}$ dimeric unit. Within the $\mathrm{VO}_{5}$ square pyramids, the apical $\mathrm{V}-\mathrm{O}$ bond is shorter than the vanadium - oxygen distances of the square base. This vanadyl $\mathrm{V}-\mathrm{O}$ bond distance is close to that calculated in various carnotite-type compounds [54] and $\mathrm{V}_{2} \mathrm{O}_{5}$ [55].

In structures 4 and $\mathbf{6}$, the vanadium atoms occupy one crystallographic site with tetrahedral environment. The tetrahedra are slightly distorted with $\mathrm{V}-\mathrm{O}$ distances in the range from $1.721(7)$ to $1.763(5) \AA$ when the oxygen atoms are shared with a $\mathrm{UO}_{7}$ polyhedron and shorter distances with $\mathrm{O}(5)$ atom not involved in uranium coordination, 1.62(1) and 1.611(6) $\AA$ for $\mathbf{4}$ and 6, respectively.

Bond - valence sums were calculated using parameters given by Burns et al. [53] for $\mathrm{U}-\mathrm{O}$ bonds and by Brese and O'Keeffe [56] for V - O bonds. Calculations resulted in values ranging from 6.00(2) to 6.19(3) v.u. for $\mathrm{U}^{6+}$ and from 5.08(5) to 5.14(4) v.u. for $\mathrm{V}^{5+}$ with oxygen valences ranging from 1.57(2) to 2.18(2) v.u.. The lowest sums correspond to $\mathrm{O}$ atoms not shared between $\mathrm{UO}_{7}$ and $\mathrm{VO}_{4}$ or $\mathrm{VO}_{5}$ polyhedra.

\section{Structural connectivity}

The structural building unit block, with labelled scheme, constituted from two edgeshared $\mathrm{UO}_{7}$ pentagonal bipyramids and two edge-shared $\mathrm{VO}_{5}$ square pyramids is shown on Fig. 1 for compounds $\mathbf{1}, \mathbf{2}$ and $\mathbf{5}$.

Compound $\mathbf{1}$ is isotypic with the mineral carnotite $\mathrm{K}_{2}\left[\left(\mathrm{UO}_{2}\right)_{2} \mathrm{~V}_{2} \mathrm{O}_{8}\right]$ and other $A_{2}\left[\left(\mathrm{UO}_{2}\right)_{2} \mathrm{~V}_{2} \mathrm{O}_{8}\right] \cdot \mathrm{nH}_{2} \mathrm{O}$ compounds where $A$ is a monovalent ion [45], $\mathrm{CsUNbO}_{6}$ [57] and $A_{2}\left[\left(\mathrm{UO}_{2}\right)_{2} \mathrm{Cr}_{2} \mathrm{O}_{8}\right] \cdot \mathrm{nH}_{2} \mathrm{O}(A=\mathrm{K}, \mathrm{Rb} \mathrm{Cs})$ [58]. The structural arrangement between the edgeshared dimers, $\mathrm{V}_{2} \mathrm{O}_{8}$, and the edge- and corner- shared pentagonal bipyramids, $\mathrm{UO}_{7}$, further linked by edge-sharing, forms sheets of composition $\left[\left(\mathrm{UO}_{2}\right)_{2} \mathrm{~V}_{2} \mathrm{O}_{8}\right]^{2-}$ parallel to $\left(\begin{array}{lll}1 & 0 & 0\end{array}\right)$ (Fig. b). The ammonium anions are located in the interlayer space and insure the cohesion of the structure.

Compound $\mathbf{3}$ is built from the same layers. The layers packing along $\boldsymbol{a}$-axis depends upon the interleaving cation. In $\mathbf{1}$, as in almost the monovalent containing 
$A_{2}\left[\left(\mathrm{UO}_{2}\right)_{2} \mathrm{~V}_{2} \mathrm{O}_{8}\right] \cdot \mathrm{xH}_{2} \mathrm{O}$ compounds, adjacent layers noted $\mathrm{P}$ are deduced by a translation, resulting in the simple PPPP sequence (Fig. 3a). In compound $\mathbf{3}$ there is a second layer, labelled $\mathrm{b}$, deduced from $\mathrm{P}$ by a $\left(\begin{array}{lll}1 & 0 & 0\end{array}\right)$ mirror plane. $\mathrm{P}$ and $\mathrm{b}$ layers alternate to yield $\mathrm{a} \mathrm{PbPb}$ sequence (Fig. 3b). Such a sequence was previously evidenced in $A\left[\left(\mathrm{UO}_{2}\right)_{2} \mathrm{~V}_{2} \mathrm{O}_{8}\right] \cdot \mathrm{xH}_{2} \mathrm{O}$ compounds containing a divalent $A$ cation [50-52].

Using the description developed by Burns et al. [59], the francevillite anion topology of the $\left[\left(\mathrm{UO}_{2}\right)_{2} \mathrm{~V}_{2} \mathrm{O}_{8}\right]^{2-}$ sheets is represented in Fig. 2a. Compounds $\mathbf{2}$ and $\mathbf{5}$ are built from sheets with the same anion topology and with the same occupation of pentagons by U, squares by $\mathrm{V}$ and empty triangles, but, in contrast with all the carnotite-type layer containing compounds described up today (Fig. 2b), half of the $\mathrm{V}_{2} \mathrm{O}_{8}$ units are reversed compared to the $\mathrm{P}$ sheets (Fig. 2c). A $\mathrm{V}_{2} \mathrm{O}_{8}$ dimmer can be referenced as $u d$ with a tetragonal pyramid that point up and one down. In P layers the dimers alternate, along [ $\left[\begin{array}{lll}0 & 1 & 0\end{array}\right]$, to form the isomer $u d / d u$, in opposite, the new anionic layer, labelled $\mathrm{P}^{\prime}$ hereafter, represents the $u d / u d$ geometrical isomer. In compound $\mathbf{5}$, a layer b' is deduced from $\mathrm{P}$ ' by a two fold axis running along $\mathbf{c}$ axis so as the stacking sequence is P'b'P'b' (Fig. 3d) while the stacking sequence in

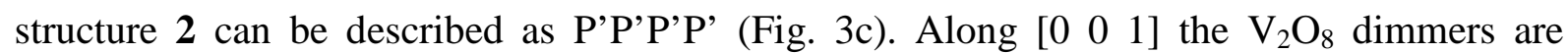
parallel.

Compounds 4 and 6 are isotypic and contain the same $\left[\left(\mathrm{UO}_{2}\right)_{2}\left(\mathrm{VO}_{4}\right)_{2}\right]^{2-}$ layer built from $\left(\mathrm{UO}_{5}\right)_{\infty}$ zig-zag chains of edge shared $\mathrm{UO}_{7}$ pentagonal bipyramids running down the $\boldsymbol{b}$ axis further connected by $\mathrm{VO}_{4}$ tetrahedra. The uranyl vanadate layer has the uranophane sheets anion topology (Fig. 4) adopted by many mineral or synthetic inorganic or hybrid organic-inorganic uranyl compounds. In 4 and 6, all the tetrahedra that share edges with one side of a uranyl chain point down $(d)$, and all the tetrahedra along the other side point up $(u)$ which corresponds to the geometrical isomer $d u / d u$ as defined by Locock et al. [60]. The three dimensional structure results from the alternate stacking of inorganic layers and sheets of protonated amines and occluded water molecules.

It should be noticed that with triethylamine, Locock and Burns [17] obtained the same structural arrangement but with another geometrical isomer of the uranyl arseniate layer whereas with dabco molecules an autunite-type uranyl arseniate layer is formed. 


\section{Interlayer space occupation}

In order to study the role of amine on the structural arrangement of the uranyl vanadates, the location and connectivity of amines in the interlayer space was systematically investigated for the single crystal studied compounds.

Projected along [ $\left[\begin{array}{ll}1 & 0\end{array}\right]$, the interleaving $\mathrm{NH}_{4}{ }^{+}$cations in $\mathbf{1}$ appears at the centre of the inoccupied triangles of the francevillite anion - type topology (Fig. 5). $\mathrm{The} \mathrm{NH}_{4}{ }^{+}$ions occupy the same position than the alkali atoms in the $A_{2}\left[\left(\mathrm{UO}_{2}\right)_{2} \mathrm{~V}_{2} \mathrm{O}_{8}\right]$ compounds. Investigation of the $\mathrm{N}-\mathrm{O}$ distances evidenced eight $\mathrm{N}$ - O contacts in a continuous range from 2.8 to $3.3 \AA$ without any $\mathrm{O}-\mathrm{N}-\mathrm{O}$ angle corresponding to a tetrahedral coordination involving hydrogen bonds, so the pseudo - alkali character of the ammonium cation dominates in this compound. Fig. 6 shows the variation of the inter-layer distance $a \sin \beta$ for the $A_{2}\left[\left(\mathrm{UO}_{2}\right)_{2} \mathrm{~V}_{2} \mathrm{O}_{8}\right]$ compounds with the ionic radii of the $8-$ coordinated $A^{+}$ions [61]. Using the value of ionic radius reported by Khan and Bauer [62] for the 8-coordinated $\mathrm{NH}_{4}{ }^{+}(1.66 \AA)$, the corresponding point does not fit with this straightforward variation, so according to Shannon [61] for the 6coordination, we should conclude that $\mathrm{NH}_{4}{ }^{+}$is not different in size from $\mathrm{Rb}^{+}$.

Although in $\mathbf{2}$ and $\mathbf{3}$ the diprotonated amines could not be localised one can imagine that they separate the inorganic layers from one another creating spacing of approximately 6.98 and $7.37 \AA$ between uranium atom planes and stabilize the structures, both through balancing the negative charge of the inorganic layer, and donating hydrogen bonds.

In $\mathbf{5}$, the $\left[\mathrm{H}_{2} \text { dmpip }\right]^{2+}$ cations, with a chair conformation, are aligned along $\left[\begin{array}{lll}0 & 0 & 1\end{array}\right]$ in the space between the $\left[\left(\mathrm{UO}_{2}\right)_{2} \mathrm{~V}_{2} \mathrm{O}_{8}\right]^{2-}$ layers. The mean plane of the diamines is inclined of about $45^{\circ}$ from the layer. As evidenced on Fig. 5, the arrangement of the diamines in the interlayer space is incompatible with the $u d / d u$ isomer. The two nitrogen atoms of the $\left[\mathrm{H}_{2} \text { dmpip }\right]^{2+}$ cation donate their hydrogen bonds to the apical oxygen atoms $\mathrm{O}(2)$ of two parallel uranyl-vanadate layers with a N1 - - - O2 distance of 2.98(2) A.

In 4 and 6 , the $\left[\mathrm{H}_{2} \text { pip }\right]^{2+}$ and $\left[\mathrm{H}_{2} d a b c o\right]^{2+}$ cations reside between the inorganic layers and are located above the $\mathrm{VO}_{4}$ tetrahedra of the $\left[\left(\mathrm{UO}_{2}\right)_{2}\left(\mathrm{VO}_{4}\right)_{2}\right]^{2-}$ uranophane layers that points down. In $\mathbf{4}$, the interleaving $\left[\mathrm{H}_{2} \text { pip }\right]^{2+}$ molecules lie almost parallel to $\left(\begin{array}{lll}1 & 0 & 0\end{array}\right)$ plane with no strong hydrogen bonds with the uranyl vanadate layer : instead, the shortest $\mathrm{N}--\mathrm{O}$ distances, 2.71(2) $\AA$ involves an oxygen of the interleaving water molecules. The $\left[\mathrm{H}_{2} p i p\right]^{2+}$ molecules adopt a boat conformation which can be present in two possible orientations related by a mirror parallel to $\left(\begin{array}{lll}0 & 0 & 1\end{array}\right)$. Thus, the site occupancy factors for the $\mathrm{C}(1), \mathrm{C}(2)$ and $\mathrm{N}(1)$ atoms, located in a general position, were fixed at 0.5 . In $\mathbf{6}$, the pseudo-trigonal $\left[\mathrm{H}_{2} \mathrm{dabco}\right]^{2+}$ cations (Fig. 7) can be found with two possible orientations modelled by half occupying the 
general positions of $\mathrm{C}(1), \mathrm{C}(2)$ and $\mathrm{N}(1)$ atoms. Moreover, a disorder presented by the $\mathrm{C}(3)-$ $\mathrm{C}(4)$ group, was taken in account by fixing at 0.25 the site occupancy for $\mathrm{C}(3)$ and $\mathrm{C}(4)$ atoms, located in a general position. The $\left[\mathrm{H}_{2} \mathrm{dabco}\right]^{2+}$ molecule are slightly distorted with $\mathrm{C}(1)-\mathrm{C}(2)$ and $\mathrm{C}(3)-\mathrm{C}(4)$ bond lengths respectively equivalent to 1.67(2) and 1.64(5) $\mathrm{\AA}$ and $\mathrm{N}(1)-\mathrm{C}$ bond lengths varying within the range [1.40 - 1.55] $\AA$. The cations are oriented such as their ammonium moities are directed toward the corner sharing oxygen atoms $\mathrm{O}(3)$ of the $\mathrm{VO}_{4}-\mathrm{UO}_{7}$ units with a strong $\mathrm{N}---\mathrm{O}(3)$ hydrogen bond lying along the $\mathrm{N}-\mathrm{N}$ axis of 2.78(1) $\AA$. That indicates the presence of a three-dimensional hydrogen bonds network that constrains the $\left[\mathrm{H}_{2} \mathrm{dabco}\right]^{2+}$ cations to lie almost perpendicular to the layers as previously observed in diamine templated uranium sulfates [26].

\section{Thermal behaviour}

For compound 1, a one-step decomposition from $\left(\mathrm{NH}_{4}\right)_{2}\left[\left(\mathrm{UO}_{2}\right)_{2} \mathrm{~V}_{2} \mathrm{O}_{8}\right]$ to $\left(\mathrm{UO}_{2}\right)_{2} \mathrm{~V}_{2} \mathrm{O}_{7}$ [63] corresponding to $6.1 \%$ weight loss in accordance with the $6.5 \%$ theoretical loss is observed between 375 and $470^{\circ} \mathrm{C}$ on the TGA curve. The thermal behavior is confirmed by high temperature X-ray diffraction experiment.

For all the amine bearing materials ( 2 to $\mathbf{6}$ ), the decomposition of the amine and the modification of the uranyl - vanadate arrangement occur in several steps between 280 and $550^{\circ} \mathrm{C}$. On the high temperature X-ray diffraction patterns a non - crystalline zone is observed between the starting uranyl - vanadate and the final product $\left(\mathrm{UO}_{2}\right)_{2} \mathrm{~V}_{2} \mathrm{O}_{7}$ [61]. The total weight losses are in agreement with the calculated values for the transformation from (Diamine) [uranyl-vanadate] to $\left(\mathrm{UO}_{2}\right)_{2} \mathrm{~V}_{2} \mathrm{O}_{7}$ (exp. / theor. (\%): 9.0/9.4 - 11.3/10.9 - 11.5/12.0 $-14.8 / 14.9-14.0 / 14.6$ for structures $2-6$ respectively).

\section{Conclusion.}

For the five studied structure directing diamines, uranyl vanadates layers with formula $\left(\mathrm{UVO}_{6}\right)^{2-}$ are formed. Two types of layers were obtained. For compounds $\mathbf{1}, \mathbf{2}, \mathbf{3}$ and $\mathbf{5}$, the $\left[\left(\mathrm{UO}_{2}\right)_{2} \mathrm{~V}_{2} \mathrm{O}_{8}\right]^{2-}$ layers are similar to that of the mineral carnotite with two geometrical isomers distinguished by the orientations of the $\mathrm{V}_{2} \mathrm{O}_{8}$ units. For compounds $\mathbf{4}$ and $\mathbf{6}$, the uranophanetype layers are built from chains of edge-shared $\mathrm{UO}_{7}$ pentagonal bipyramids connected through $\mathrm{VO}_{4}$ tetrahedra. In all the compounds, the diprotonated amines reside between the inorganic layers, balancing charge and donating hydrogen bonds to the layers. For all 
compounds, thermal decomposition led to the divanadate $\left(\mathrm{UO}_{2}\right)_{2} \mathrm{~V}_{2} \mathrm{O}_{7}$. Further experiments using other amine structure directing agents to built three-dimensional uranyl-vanadate frameworks are in progress.

\section{Acknowledgment.}

The authors gratefully thank Catherine Méliet (UCCS, USTL) and Marc Bria (SCM RMN-

RPE, USTL) for their assistance in collecting and interpreting the ${ }^{13} \mathrm{C}$ NMR spectra. The "Fonds Européen de Développement Régional (FEDER)", "CNRS", "Région Nord Pas-deCalais" and "Ministère de l'Education Nationale de l'Enseignement Supérieur et de la Recherche" are acknowledged for fundings of X-ray diffractometers. 
Table 1 : Amine molecules of the studied $\mathrm{UO}_{3}-\mathrm{V}_{2} \mathrm{O}_{5}$-amine systems.

\begin{tabular}{|l|l|l|c|}
\hline Name & Formula & Origin & Compound \\
\hline 1,2 - Ethylenediamine (en) & $\mathrm{H}_{2} \mathrm{~N}\left(\mathrm{CH}_{2}\right)_{2} \mathrm{NH}_{2}$ & ACROS, 99\%, d=0.899 & $\mathbf{1}$ and 2 \\
\hline 1,3 - Diaminopropane (dap) & $\mathrm{H}_{2} \mathrm{~N}\left(\mathrm{CH}_{2}\right)_{3} \mathrm{NH}_{2}$ & ACROS, 99\%, d=0.870 & $\mathbf{3}$ \\
\hline Piperazine (pip) & ACROS, 99\% & $\mathbf{4}$ \\
\hline 1 - Methylpiperazine (mpip) & ACROS, 99\% & $\mathbf{5}$ \\
\hline $1,4-$ Diazabicyclo[2,2,2]octane & dabco $)$ & ACROS, 97\% & $\mathbf{6}$ \\
\hline
\end{tabular}




\begin{tabular}{|c|c|c|c|c|}
\hline Compound $\mathbf{n}^{\circ}$ & 1 & 4 & 5 & 6 \\
\hline Chemical formula & $\left(\mathrm{NH}_{4}\right)_{2}\left[\left(\mathrm{UO}_{2}\right)_{2} \mathrm{~V}_{2} \mathrm{O}_{8}\right]$ & $\left(\mathrm{H}_{2}\right.$ pip $)\left[\left(\mathrm{UO}_{2}\right)_{2}\left(\mathrm{VO}_{4}\right)_{2}\right] \cdot 0,8 \mathrm{H}_{2} \mathrm{O}$ & $\left(\mathrm{H}_{2} d m p i p\right)\left[\left(\mathrm{UO}_{2}\right)_{2} \mathrm{~V}_{2} \mathrm{O}_{8}\right]$ & $\left(\mathrm{H}_{2} d a b c o\right)\left[\left(\mathrm{UO}_{2}\right)_{2}\left(\mathrm{VO}_{4}\right)_{2}\right]$ \\
\hline \multicolumn{5}{|l|}{ Crystallographic data } \\
\hline Formula weight $\left(\mathrm{g} \cdot \mathrm{mol}^{-1}\right)$ & 806 & 872.5 & 886.1 & 884.1 \\
\hline Crystal system & monoclinic & monoclinic & monoclinic & monoclinic \\
\hline Space group & $P 2{ }_{l} / c$ & $C 2 / m$ & $P 2{ }_{1} / b$ & $C 2 / m$ \\
\hline \multirow{4}{*}{ Unit - cell dimensions $(\AA)$} & $a=6.894(2)$ & $a=15.619(2)$ & $a=9.315(2)$ & $a=17.440(2)$ \\
\hline & $b=8.384(3)$ & $b=7.1802(8)$ & $b=8.617(2)$ & $b=7.1904(9)$ \\
\hline & $c=10.473(4)$ & $c=6.9157(8)$ & $c=10.5246(2)$ & $c=6.8990(8)$ \\
\hline & $\beta=106.066(5)$ & $\beta=101.500(2)$ & $\gamma=114.776(2)$ & $\beta=98.196(2)$ \\
\hline Cell volume $\left(\AA^{3}\right)$ & $581.7(4)$ & $760.0(2)$ & $767.0(2)$ & $856.3(2)$ \\
\hline $\mathrm{Z}$ & 2 & 2 & 2 & 2 \\
\hline Density, calculated $\left(\mathrm{g} \cdot \mathrm{cm}^{-3}\right)$ & $4.600(3)$ & $3.814(1)$ & $3.838(1)$ & 3.4279() \\
\hline$F(000)$ & 696 & 768 & 784 & 780 \\
\hline \multicolumn{5}{|l|}{ Intensity collection } \\
\hline Wavelength $(\AA)$ & $0.71069(\mathrm{MoK} \alpha)$ & $0.71069(\mathrm{MoK} \alpha)$ & $0.71069(\mathrm{MoK} \alpha)$ & $0.71069(\mathrm{MoK \alpha})$ \\
\hline$\theta$ range $(\mathrm{deg})$ & $3.07-28.67$ & $3.01-23.27$ & $2.41-27.95$ & $2.98-28.44$ \\
\hline \multirow[t]{3}{*}{ Data collected } & $-9 \leq h \leq 9$ & $-17 \leq h \leq 17$ & $-12 \leq h \leq 12$ & $-23 \leq h \leq 23$ \\
\hline & $-11 \leq k \leq 11$ & $-7 \leq k \leq 7$ & $-13 \leq k \leq 13$ & $-9 \leq k \leq 9$ \\
\hline & $-13 \leq l \leq 13$ & $-7 \leq l \leq 7$ & $-10 \leq l \leq 10$ & $-9 \leq l \leq 9$ \\
\hline No. of reflections measured & 4549 & 2005 & 5425 & 3549 \\
\hline No. of independent reflections & 1364 & 590 & 1633 & 1105 \\
\hline Redundancy & 3.335 & 3.40 & 3.32 & 3.212 \\
\hline $\begin{array}{l}\text { No. of unique reflections } \\
\qquad(I>3 \sigma(I))\end{array}$ & 1186 & 530 & 1250 & 1027 \\
\hline$\mu(\mathrm{MoK} \alpha)\left(\mathrm{mm}^{-1}\right)$ & 29.373 & 22.502 & 22.296 & 19.971 \\
\hline$T_{\min } / T_{\max }$ & 0.466 & 0.367 & 0.680 & 0.202 \\
\hline$R\left(F^{2}\right)_{\text {int }}$ & 0.0397 & 0.0313 & 0.0492 & 0.0319 \\
\hline \multicolumn{5}{|l|}{ Refinement } \\
\hline No. of parameters & 83 & 62 & 110 & 77 \\
\hline Weighting scheme & $1 / \sigma^{2}$ & $1 / \sigma^{2}$ & $1 / \sigma^{2}$ & $1 / \sigma^{2}$ \\
\hline$R(F)$ obs/all & $0.0276 / 0.0340$ & $0.0214 / 0.0240$ & $0.0332 / 0.0502$ & $0.0238 / 0.0250$ \\
\hline w $R(F)$ obs/all & $0.0296 / 0.0304$ & $0.0244 / 0.0249$ & $0.0291 / 0.0306$ & $0.0300 / 0.0302$ \\
\hline $\operatorname{Max}, \min \Delta \rho\left(\mathrm{e} . \AA^{-3}\right)$ & $1.97 /-1.84$ & $0.78 /-1.01$ & $2.32 /-1.57$ & $1.89 /-1.20$ \\
\hline
\end{tabular}

Table 2 : Crystal data, intensity collection and structure refinement parameters for $\left(\mathrm{NH}_{4}\right)_{2}\left[\left(\mathrm{UO}_{2}\right)_{2} \mathrm{~V}_{2} \mathrm{O}_{8}\right](\mathbf{1}),\left(\mathrm{H}_{2}\right.$ pip $)\left[\left(\mathrm{UO}_{2}\right)_{2}\left(\mathrm{VO}_{4}\right)_{2}\right] \cdot 0,8 \mathrm{H}_{2} \mathrm{O}(\mathbf{4})$, $\left(\mathrm{H}_{2}\right.$ dmpip $)\left[\left(\mathrm{UO}_{2}\right)_{2} \mathrm{~V}_{2} \mathrm{O}_{8}\right](\mathbf{5})$ and $\left(\mathrm{H}_{2}\right.$ dabco $)\left[\left(\mathrm{UO}_{2}\right)_{2}\left(\mathrm{VO}_{4}\right)_{2}\right](\mathbf{6})$. 
Table 3. Atomic coordinates and isotropic displacement parameters (in $\AA^{2}$ ) for $\left(\mathrm{NH}_{4}\right)_{2}\left[\left(\mathrm{UO}_{2}\right)_{2} \mathrm{~V}_{2} \mathrm{O}_{8}\right]$ (1).

\begin{tabular}{lccccc}
\hline Atom & Wyck. & $\mathbf{x}$ & $\mathbf{y}$ & $\mathbf{z}$ & $\mathbf{U}_{\mathbf{e q}}$ \\
\hline $\mathrm{U} 1$ & $4 e$ & $0.01539(4)$ & $0.47727(3)$ & $0.81974(2)$ & $0.0110(2)$ \\
$\mathrm{V} 1$ & $4 e$ & $0.1147(2)$ & $0.8516(2)$ & $0.0557(2)$ & $0.0122(4)$ \\
O1 & $4 e$ & $0.2776(8)$ & $0.4265(7)$ & $0.8795(5)$ & $0.020(2)$ \\
O2 & $4 e$ & $-0.2457(9)$ & $0.5260(6)$ & $0.7598(5)$ & $0.019(2)$ \\
O3 & $4 e$ & $0.0406(8)$ & $0.0607(6)$ & $0.1079(5)$ & $0.016(2)$ \\
O4 & $4 e$ & $0.0418(8)$ & $0.6553(6)$ & $-0.0044(4)$ & $0.016(2)$ \\
O5 & $4 e$ & $0.3484(9)$ & $0.8708(7)$ & $0.0648(5)$ & $0.025(2)$ \\
O6 & $4 e$ & $0.0930(8)$ & $0.7909(6)$ & $0.2192(5)$ & $0.016(2)$ \\
N1 & $4 e$ & $-0.458(2)$ & $0.7697(9)$ & $0.8626(7)$ & $0.029(3)$ \\
\hline
\end{tabular}

Table 4. Atomic coordinates and isotropic displacement parameters (in $\AA^{2}$ ) for $\left(\mathrm{H}_{2}\right.$ dmpip) $\left[\left(\mathrm{UO}_{2}\right)_{2} \mathrm{~V}_{2} \mathrm{O}_{8}\right](\mathbf{5})$

\begin{tabular}{lccccc}
\hline Atom & Wyck. & $\mathbf{x}$ & $\mathbf{y}$ & $\mathbf{z}$ & $\mathbf{U}_{\mathbf{e q}}$ \\
\hline $\mathrm{U} 1$ & $4 e$ & $0.48421(4)$ & $0.47738(4)$ & $-0.31760(3)$ & $0.0125(2)$ \\
$\mathrm{V} 1$ & $4 e$ & $0.4327(2)$ & $0.1248(2)$ & $-0.4674(2)$ & $0.0149(7)$ \\
O1 & $4 e$ & $0.6969(8)$ & $0.5718(8)$ & $-0.3076(7)$ & $0.024(3)$ \\
O2 & $4 e$ & $0.2702(7)$ & $0.3856(8)$ & $-0.3308(7)$ & $0.020(3)$ \\
O3 & $4 e$ & $0.5371(8)$ & $0.0699(8)$ & $-0.5981(6)$ & $0.017(3)$ \\
O4 & $4 e$ & $0.5028(8)$ & $0.3475(8)$ & $-0.5114(6)$ & $0.016(3)$ \\
O5 & $4 e$ & $0.2473(7)$ & $0.0417(8)$ & $-0.4949(7)$ & $0.022(3)$ \\
O6 & $4 e$ & $0.4657(8)$ & $0.1971(7)$ & $-0.2998(6)$ & $0.019(3)$ \\
N1 & $4 e$ & $0.004(2)$ & $0.488(2)$ & $-0.3662(9)$ & $0.061(6)$ \\
C1 & $4 e$ & $0.095(2)$ & $0.648(2)$ & $-0.424(2)$ & $0.041(5)$ \\
C2 & $4 e$ & $-0.113(2)$ & $0.350(2)$ & $-0.436(2)$ & $0.043(5)$ \\
C3 & $4 e$ & $-0.015(2)$ & $0.487(2)$ & $-0.222(2)$ & $0.062(8)$ \\
\hline
\end{tabular}


Table 5. Atomic coordinates and isotropic displacement parameters (in $\AA^{2}$ ) for $\left(\mathrm{H}_{2}\right.$ pip $)\left[\left(\mathrm{UO}_{2}\right)_{2}\left(\mathrm{VO}_{4}\right)_{2}\right] .0,8 \mathrm{H}_{2} \mathrm{O}$ (4) (bold type) and $\left(\mathrm{H}_{2}\right.$ dabco $)\left[\left(\mathrm{UO}_{2}\right)_{2}\left(\mathrm{VO}_{4}\right)_{2}\right](6)$ (italic type).

\begin{tabular}{|c|c|c|c|c|c|c|}
\hline Atom & Site & Occ. & $\mathbf{x}$ & $\mathbf{y}$ & $\mathbf{z}$ & $\mathbf{U}_{\text {eq/iso* }}$ \\
\hline U1 & $4 i$ & & $0.75640(3)$ & $\mathbf{0}$ & $-0.11646(6)$ & $0.0118(2)$ \\
\hline$U 1$ & $4 i$ & & $0.75602(2)$ & 0 & $-0.11813(3)$ & $0.0138(2)$ \\
\hline V1 & $4 i$ & & $0.7204(2)$ & 0 & $-0.6690(2)$ & $0.0108(6)$ \\
\hline$V 1$ & $4 i$ & & $0.71988(7)$ & 0 & $-0.6700(2)$ & $0.0138(3)$ \\
\hline 01 & $4 i$ & & $0.8722(5)$ & 0 & $-0.036(1)$ & $0.020(3)$ \\
\hline$O 1$ & $4 i$ & & $0.8588(3)$ & 0 & $-0.0535(8)$ & $0.027(2)$ \\
\hline $\mathbf{O 2}$ & $4 i$ & & $0.6409(5)$ & $\mathbf{0}$ & $-0.191(2)$ & $0.026(3)$ \\
\hline O2 & $4 i$ & & $0.6528(3)$ & 0 & $-0.1811(8)$ & $0.027(2)$ \\
\hline $\mathbf{O 3}$ & $4 i$ & & $0.7838(5)$ & 0 & $-0.435(1)$ & $0.020(3)$ \\
\hline 03 & $4 i$ & & $0.7763(3)$ & 0 & $-0.4412(7)$ & $0.020(2)$ \\
\hline 04 & $8 j$ & & $0.7433(4)$ & $-0.1807(7)$ & $-0.8236(7)$ & $0.021(2)$ \\
\hline$O 4$ & $8 j$ & & $0.7428(2)$ & $-0.1799(5)$ & $-0.8221(5)$ & $0.024(2)$ \\
\hline 05 & $4 i$ & & $0.6179(6)$ & 0 & - $0.659(2)$ & $0.032(3)$ \\
\hline$O 5$ & $4 i$ & & $0.6289(4)$ & 0 & $-0.6494(9)$ & $0.038(2)$ \\
\hline O6w & $4 g$ & $0.42(2)$ & 0.5 & - $0.184(2)$ & 0 & $0.014(6) *$ \\
\hline N1 & $8 \mathbf{j}$ & 0.5 & $0.504(2)$ & $-0.386(2)$ & $-0.667(2)$ & $0.025(4) *$ \\
\hline C1 & $8 \mathbf{j}$ & 0.5 & $0.532(2)$ & $-0.432(2)$ & - $0.673(2)$ & $0.022(5) *$ \\
\hline $\mathrm{C2}$ & $8 \mathbf{j}$ & 0.5 & $0.482(2)$ & $-0.304(2)$ & $-0.543(2)$ & $0.026(5) *$ \\
\hline$N 1$ & $8 j$ & 0.5 & $0.0660(5)$ & $-0.037(2)$ & $0.453(2)$ & $0.033(3) *$ \\
\hline$C 1$ & $8 j$ & 0.5 & $0.9325(9)$ & $0.153(3)$ & $0.371(2)$ & $0.059(7)$ \\
\hline$C 2$ & $8 j$ & 0.5 & $0.0182(8)$ & $0.118(2)$ & $0.296(3)$ & $0.068(7)$ \\
\hline$C 3$ & $8 j$ & 0.25 & $0.040(2)$ & $0.163(4)$ & $0.447(6)$ & $0.054(9) *$ \\
\hline$C 4$ & $8 j$ & 0.25 & $0.946(2)$ & $0.154(5)$ & $0.451(7)$ & $0.047(9) *$ \\
\hline
\end{tabular}


Table 6. Principal interatomic distances (Å) for $\mathbf{1}$ and $\mathbf{5}$.

\begin{tabular}{|c|c|c|c|}
\hline \multicolumn{2}{|c|}{ Compound 1} & \multicolumn{2}{|c|}{ Compound $\mathbf{5}$} \\
\hline U1 - O1 & $1.793(5)$ & $\mathrm{U} 1-\mathrm{O} 1$ & $1.802(7)$ \\
\hline $\mathrm{U} 1$ - O2 & $1.782(6)$ & $\mathrm{U} 1-\mathrm{O} 2$ & $1.816(6)$ \\
\hline $\mathrm{U} 1-\mathrm{O} 3^{\mathrm{iv}}$ & $2.295(6)$ & $\mathrm{U} 1-\mathrm{O} 3^{\mathrm{i}}$ & $2.340(6)$ \\
\hline $\mathrm{U} 1-\mathrm{O} 4^{\mathrm{i}}$ & $2.338(5)$ & $\mathrm{U} 1-\mathrm{O} 4 \ldots$ & $2.368(7)$ \\
\hline $\mathrm{U} 1-\mathrm{O} 4^{\mathrm{ii}}$ & $2.356(5)$ & $\mathrm{U} 1-\mathrm{O} 4^{\mathrm{iii}}$ & $2.319(7)$ \\
\hline $\mathrm{U} 1-\mathrm{O} 6^{\mathrm{i}}$ & $2.369(5)$ & $\mathrm{U} 1$ - O6 & $2.356(7)$ \\
\hline $\mathrm{U} 1-\mathrm{O} 6^{\mathrm{iii}}$ & $2.342(5)$ & $\mathrm{U} 1-\mathrm{O} 6^{\mathrm{ii}}$ & $2.327(7)$ \\
\hline $\mathrm{V} 1-\mathrm{O} 3^{\mathrm{v}}$ & $1.946(5)$ & $\mathrm{V} 1$ - O3 & $1.857(8)$ \\
\hline $\mathrm{V} 1-\mathrm{O} 3^{\mathrm{V}}$ & $1.899(5)$ & $\mathrm{V} 1-\mathrm{O} 3^{\mathrm{iv}}$ & $1.940(8)$ \\
\hline $\mathrm{V} 1$ - O4 & $1.784(5)$ & V1 - O4 & $1.809(7)$ \\
\hline $\mathrm{V} 1-\mathrm{O} 5$ & $1.596(6)$ & V1 - O5 & $1.594(6)$ \\
\hline \multirow[t]{7}{*}{$\mathrm{V} 1$ - O6 } & $1.832(6)$ & V1 - O6 & $1.853(6)$ \\
\hline & & $\mathrm{V} 1-\mathrm{V} 1^{\mathrm{iv}}$ & $2.988(3)$ \\
\hline & & $\mathrm{N} 1-\mathrm{O} 2$ & $2.98(2)$ \\
\hline & & $\mathrm{N} 1-\mathrm{C} 1$ & $1.42(2)$ \\
\hline & & $\mathrm{N} 1-\mathrm{C} 2$ & $1.43(2)$ \\
\hline & & $\mathrm{N} 1-\mathrm{C} 3$ & $1.53(2)$ \\
\hline & & $\mathrm{C} 1-\mathrm{C} 2^{\mathrm{vi}}$ & $1.48(2)$ \\
\hline
\end{tabular}

Symmetry codes for 1 (i) $-\mathrm{x},-\mathrm{y}, 1-\mathrm{z}$; (ii) $-\mathrm{x}, 1-\mathrm{y}, 1-\mathrm{z}$; (iii) $\mathrm{x}, 3 / 2-\mathrm{y}, 1 / 2+\mathrm{z}$; (iv) $\mathrm{x}, 1 / 2-\mathrm{y}, 1 / 2+\mathrm{z}(\mathrm{v}) ;-\mathrm{x}, 1$ $-\mathrm{y},-\mathrm{z}$; (vi) $-1+\mathrm{x}, 1 / 2-\mathrm{y}, 3 / 2+\mathrm{z}$;(vii) $-1-\mathrm{x},-\mathrm{y}, 1-\mathrm{z}$; for 5 (i) $1-\mathrm{x}, 1 / 2-\mathrm{y}, 1 / 2+\mathrm{z}$; (ii) $\mathrm{x}, 1 / 2+\mathrm{y},-1 / 2-\mathrm{z}$; (iii) $1-\mathrm{x}, 1-\mathrm{y},-1-\mathrm{z}$; (iv) $1-\mathrm{x},-\mathrm{y},-1-\mathrm{z}$; (v) $1-\mathrm{x}, 1 / 2-\mathrm{y},-1 / 2+\mathrm{z}$; (vi) $-\mathrm{x}, 1-\mathrm{y},-1-\mathrm{z}$ 
Table 7. Principal interatomic distances (Å) for $\mathbf{4}$ and $\mathbf{6}$.

\begin{tabular}{lclr}
\hline & Compound 4 & & Compound 6 \\
\hline $\mathrm{U} 1-\mathrm{O} 1$ & $1.775(8)$ & $\mathrm{U} 1-\mathrm{O} 1$ & $1.784(5)$ \\
$\mathrm{U} 1-\mathrm{O} 2$ & $1.783(8)$ & $\mathrm{U} 1-\mathrm{O} 2$ & $1.791(5)$ \\
$\mathrm{U} 1-\mathrm{O} 3$ & $2.326(7)$ & $\mathrm{U} 1-\mathrm{O} 3$ & $2.306(5)$ \\
$\mathrm{U} 1-\mathrm{O} 4^{\mathrm{i}}$ & $2.448(5)$ & $\mathrm{U} 1-\mathrm{O} 4^{\mathrm{i}}$ & $2.456(4)$ \\
$\mathrm{U} 1-\mathrm{O} 4^{\mathrm{ii}}$ & $2.330(5)$ & $\mathrm{U} 1-\mathrm{O} 4^{\mathrm{ii}}$ & $2.339(4)$ \\
$\mathrm{U} 1-\mathrm{O} 4^{\mathrm{iii}}$ & $2.330(5)$ & $\mathrm{U} 1-\mathrm{O} 4^{\mathrm{iii}}$ & $2.339(4)$ \\
$\mathrm{U} 1-\mathrm{O} 4^{\mathrm{iv}}$ & $2.448(5)$ & $\mathrm{U} 1-\mathrm{O} 4^{\mathrm{iv}}$ & $2.456(4)$ \\
& & & \\
$\mathrm{V} 1-\mathrm{O} 3$ & $1.721(7)$ & $\mathrm{V} 1-\mathrm{O} 3$ & $1.737(5)$ \\
$\mathrm{V} 1-\mathrm{O} 4$ & $1.763(5)$ & $\mathrm{V} 1-\mathrm{O} 4$ & $1.747(4)$ \\
$\mathrm{V} 1-\mathrm{O} 4^{\mathrm{v}}$ & $1.763(5)$ & $\mathrm{V} 1-\mathrm{O} 4^{\mathrm{v}}$ & $1.747(4)$ \\
$\mathrm{V} 1-\mathrm{O} 5$ & $1.62(1)$ & $\mathrm{V} 1-\mathrm{O} 5$ & $1.613(7)$ \\
& & & \\
$\mathrm{C} 1-\mathrm{C} 2$ & $1.59(2)$ & $\mathrm{C} 1-\mathrm{C} 2^{\mathrm{vii}}$ & $1.67(2)$ \\
& & $\mathrm{C} 3-\mathrm{C} 4^{\mathrm{xiv}}$ & $1.64(5)$ \\
$\mathrm{N} 1^{\mathrm{xiv}}-\mathrm{C} 1$ & $1.38(2)$ & $\mathrm{N} 1^{\mathrm{xii}}-\mathrm{C} 1$ & $1.47(2)$ \\
$\mathrm{N} 1^{\mathrm{xii}}-\mathrm{C} 2$ & $1.54(2)$ & $\mathrm{N} 1^{\mathrm{v}}-\mathrm{C} 2$ & $1.40(2)$ \\
& & $\mathrm{N} 1-\mathrm{C} 3$ & $1.51(3)$ \\
& & $\mathrm{N} 1-\mathrm{C} 4^{\mathrm{x}}$ & $1.55(4)$ \\
$\mathrm{N}^{\mathrm{i}}{ }^{\mathrm{xii}}-\mathrm{O} 6 \mathrm{Ow}$ & $2.71(2)$ & $\mathrm{N} 1^{\mathrm{vii}}-\mathrm{O} 3$ & $2.78(1)$ \\
$\mathrm{N}^{\mathrm{x}}-\mathrm{O} 6 \mathrm{w}$ & $2.71(2)$ & $\mathrm{N} 1^{\mathrm{viii}}-\mathrm{O} 3$ & $2.78(1)$ \\
\hline
\end{tabular}

Symmetry codes (i) $-\mathrm{x},-\mathrm{y}, 1-\mathrm{z}$; (ii) $3 / 2-\mathrm{x},-1 / 2-\mathrm{y},-1-\mathrm{z}$; (iii) $3 / 2+\mathrm{x}, 1 / 2-\mathrm{y},-1+\mathrm{z}$; (iv) $1 / 2+\mathrm{x}, 1 / 2-\mathrm{y}, 1+\mathrm{z}$; (v) $1 / 2+\mathrm{x}, 1 / 2-\mathrm{y}, \mathrm{z}$; (vi) $3 / 2-\mathrm{x},-1 / 2-\mathrm{y},-2-\mathrm{z}$; (vii) $1-\mathrm{x},-\mathrm{y},-\mathrm{z}$; (viii) $1+\mathrm{x},-\mathrm{y}, \mathrm{z}$; (ix) $2+\mathrm{x},-\mathrm{y}, 1+\mathrm{z}$; (x) $1+\mathrm{x},-\mathrm{y}, 1+\mathrm{z}$; (xi) $3 / 2+\mathrm{x}, 1 / 2-\mathrm{y}, \mathrm{z}$; (xii) $1-\mathrm{x},-\mathrm{y}, 1-\mathrm{z}$; (xiii) $\mathrm{x},-\mathrm{y}, 1+\mathrm{z}$; (xiv) $-1-\mathrm{x},-\mathrm{y},-\mathrm{z}$; (xv) $-1 / 2+\mathrm{x}, 1 / 2-\mathrm{y}, \mathrm{z}$;(xvi) $2-\mathrm{x},-\mathrm{y}, 1-\mathrm{z}$ 
Table 8 : Structure refinement parameters for $\left(\mathrm{H}_{2}\right.$ en $)\left[\left(\mathrm{UO}_{2}\right)_{2} \mathrm{~V}_{2} \mathrm{O}_{8}\right](2)$ and $\left(\mathrm{H}_{2}\right.$ dap $)\left[\left(\mathrm{UO}_{2}\right)_{2} \mathrm{~V}_{2} \mathrm{O}_{8}\right](3)$

\begin{tabular}{lll}
\hline Compound n & \multicolumn{1}{c}{2} & \multicolumn{1}{c}{$\mathbf{3}$} \\
\hline Chemical formula & $\left(\mathrm{H}_{2}\right.$ en $)\left[\left(\mathrm{UO}_{2}\right)_{2} \mathrm{~V}_{2} \mathrm{O}_{8}\right]$ & $\left(\mathrm{H}_{2}\right.$ dap $)\left[\left(\mathrm{UO}_{2}\right)_{2} \mathrm{~V}_{2} \mathrm{O}_{8}\right]$ \\
Crystallographic data & & \\
Formula weight $\left(\mathrm{g} \cdot \mathrm{mol}^{-1}\right)$ & 832 & 846.1 \\
Crystal system & monoclinic & orthorhombic \\
Space group & $P 21 / \mathrm{a}$ & Pmcn \\
Unit - cell dimensions $(\AA)$ & $a=13.9816(6)$ & $a=14.7363(8)$ \\
& $b=8.6165(3)$ & $b=8.6379(4)$ \\
& $c=10.4237(3)$ & $c=10.4385(4)$ \\
Cell volume $\left(\AA^{3}\right)$ & $\gamma=93.125(3)$ & \\
$Z$ & $1253.91(9)$ & $1327.5(2)$ \\
Density, calculated $\left(\mathrm{g} \cdot \mathrm{cm}^{-3}\right)$ & 4 & 4 \\
Refinement & 4.406 & 4.232 \\
Rp / Rwp & & \\
Robs / Rwobs & $0.0133 / 0.0180$ & $0.0168 / 0.0258$ \\
Rall / Rwall & $0.0634 / 0.0573$ & $0.0811 / 0.0815$ \\
Rexp & $0.0679 / 0.0579$ & $0.0959 / 0.0850$ \\
\hline
\end{tabular}


Table 9. Atomic coordinates and isotropic displacement parameters (in $\AA^{2}$ ) for $\left(\mathrm{H}_{2}\right.$ en $)\left[\left(\mathrm{UO}_{2}\right)_{2} \mathrm{~V}_{2} \mathrm{O}_{8}\right]$ (2).

\begin{tabular}{lccccc}
\hline Atom & Wyck. & $\mathbf{x}$ & $\mathbf{y}$ & $\mathbf{z}$ & $\mathbf{U}_{\text {iso/eq }}$ \\
\hline $\mathrm{U} 1$ & $4 e$ & $0.2367(4)$ & $-0.2646(9)$ & $0.2617(3)$ & $0.009(2)$ \\
$\mathrm{U} 2$ & $4 e$ & $0.2576(5)$ & $-0.236(1)$ & $0.6282(3)$ & $0.009(2)$ \\
V1 & $4 e$ & $0.276(2)$ & $0.107(2)$ & $0.470(2)$ & $0.009(2)$ \\
V2 & $4 e$ & $0.679(2)$ & $0.386(3)$ & $0.092(2)$ & $0.009(2)$ \\
O1 & $4 e$ & $0.3849(6)$ & $-0.232(3)$ & $0.608(3)$ & 0.006 \\
O2 & $4 e$ & $0.1306(4)$ & $-0.242(1)$ & $0.650(2)$ & 0.006 \\
O3 & $4 e$ & $0.3649(3)$ & $-0.259(3)$ & $0.257(4)$ & 0.006 \\
O4 & $4 e$ & $0.1086(4)$ & $-0.2723(9)$ & $0.265(2)$ & 0.006 \\
O5 & $4 e$ & $0.241(2)$ & $-0.0941(9)$ & $0.4378(3)$ & 0.006 \\
O6 & $4 e$ & $0.387(2)$ & $0.144(6)$ & $0.441(5)$ & 0.006 \\
O7 & $4 e$ & $0.738(2)$ & $0.5924(9)$ & $0.0464(3)$ & 0.006 \\
O8 & $4 e$ & $0.570(2)$ & $0.402(5)$ & $0.053(5)$ & 0.006 \\
O9 & $4 e$ & $0.2202(8)$ & $0.198(7)$ & $0.3497(9)$ & 0.006 \\
O10 & $4 e$ & $0.7336(3)$ & $0.463(1)$ & $0.248(2)$ & 0.006 \\
O11 & $4 e$ & $0.267(2)$ & $0.321(5)$ & $0.5411(9)$ & 0.006 \\
O12 & $4 e$ & $0.2627(5)$ & $0.036(2)$ & $0.638(2)$ & 0.006 \\
\hline
\end{tabular}




\section{References}

1 I. Duribreux, C. Dion, M. Saadi, F. Abraham, J. Solid State Chem. 146 (1999) 258.

2 C. Dion, S. Obbade, E. Raekelboom, M. Saadi, F. Abraham, J. Solid State Chem. 155 (2000) 342 .

3 M. Saadi, C. Dion, F. Abraham, J. Solid State Chem. 150 (2000) 72.

4 S. Obbade, C. Dion, L. Duvieubourg, M. Saadi, F. Abraham, J. Solid State Chem. 173 (2003) 1.

5 I. Duribreux, M. Saadi, S. Obbade, C. Dion, F. Abraham, J. Solid State Chem. 172 (2003) 351 .

6 S. Obbade, C. Dion, M. Saadi, F. Abraham, J. Solid State Chem. 177 (2004) 1567.

7 S. Obbade, C. Dion, M. Saadi, S. Yagoubi, F. Abraham. J. Solid State Chem 177 (2004) 3909.

8 S. Obbade, C. Dion, M. Rivenet, M. Saadi, F. Abraham. J. Solid State Chem. 177 (2004) 2058.

9 P.S. Halasyamani, R.J. Francis, S.M. Walker, D. O'Hare, Inorg. Chem. 38 (1999) 271.

10 S.V. Krivovichev, P.C. Burns, J. Solid State Chem. 170 (2003) 106.

11 S.V. Krivovichev, C.L. Cahill, E.V. Nazarchuk, P.C. Burns, T. Armbruster, W. Depmeier, Microporous and Mesoporous Materials 78 (2005) 209.

12 S.V. Krivovichev, P.C. Burns, T. Armbruster, E.V. Nazarchuk, W. Depmeier, Microporous and Mesoporous Materials 78 (2005) 217.

13 S.V. Krivovichev, T. Armbruster, D.Y. Chernyshov, P.C. Burns, E.V. Nazarchuk, W. Depmeier, Microporous and Mesoporous Materials 78 (2005) 225.

14 R.J. Francis, J. Drewitt, P.S. Halasyamani, C. Ranganathachar, D. O'Hare, W. Clegg, S.J. Teat, Chem. Commun. (1998) 279.

15 J.A. Danis, W.H. Runde, B. Scott, J. Fettinger, B. Eichhorn, Chem. Commun. (2001) 2378 .

16 J.A. Danis, H.T. Hawkins, B.L. Scott, W.H. Runde, B.E. Scheetz, B.W. Eichhorn, Polyhedron 19 (2000) 1551.

17 A.J. Locock, P.C. Burns, J. Solid State Chem. 177 (2004) 2675.

18 M.B. Doran, C.L. Stuart, A.J. Norquist, D. O'Hare, Chem. Mater. 16 (2004) 565.

19 M. Doran, S.M. Walker, D. O'Hare, Chem. Commun. (2001) 1988. 
20 S.V. Krivovichev, V. Kahlenberg, I.G. Tananaev, R. Kaindl, E. Mersdorf, B.F. Myasoedov, J. Am. Chem. Soc. 127 (2005) 1072.

21 P.M. Almond, T.E. Albrecht - Schmitt, Inorg. Chem. 42 (2003) 5693.

22 M.B. Doran, A.J. Norquist, D. O'Hare, Inorg. Chem. 42 (2003) 6989.

23 A.J. Norquist, M.B. Doran, P.M. Thomas, D. O'Hare, Dalton Trans. (2003) 1168.

24 A.J. Norquist, M.B. Doran, P.M. Thomas, D. O'Hare, Inorg. Chem. 42 (2003) 5949.

25 A.J. Norquist, M.B. Doran, D. O'Hare, Solid State Sciences 5 (2003) 1149.

26 A.J. Norquist, P.M. Thomas, M.B. Doran, D. O'Hare, Chem. Mater. 14 (2002) 5179.

27 M. Doran, A.J. Norquist, D. O'Hare, Chem. Comm. (2002) 2946.

28 P.M. Thomas, A.J. Norquist, M.B. Doran, D. O'Hare, J. Mater. Chem. 13 (2003) 88.

29 M.B. Doran, A.J. Norquist, C.L. Stuart, D. O'Hare, Acta Crystallogr. E60 (2004) m996; M.B. Doran, A.J. Norquist, D. O'Hare, Acta Crystallogr. E59 (2003) m762; M.B. Doran, A.J. Norquist, D. O'Hare, Acta Crystallogr. E59 (2003) m765; M.B. Doran, A.J. Norquist, D. O'Hare, Acta Crystallogr. E59 (2003) m373; C.L. Stuart, M.B. Doran, A.J. Norquist, D. O'Hare, Acta Crystallogr. E59 (2003) m446.

30 A.J. Norquist, M.B. Doran, D. O'Hare, Inorg. Chem. 44 (2005) 3837.

31 M.B. Doran, B.E. Cockbain, A.J. Norquist, D. O'Hare, Dalton Trans. (2004) 3810.

32 X. Wang, J. Huang, A.J. Jacobson, J. Am. Chem. Soc. 124 (2002) 15190.

33 R.J. Francis, P.S. Halasyamani, J.S. Bee, D. O'Hare, J. Am. Chem. Soc. 121 (1999) 1609.

34 R.J. Francis, P.S. Halasyamani, D. O'Hare, Angew. Chem. Int. Ed. 37 (1998) 2214.

35 S. Allen, S. Barlow, P.S. Halasyamani, J.F.W. Mosselmans, D. O'Hare, S.M. Walker, R.I. Walton, Inorg. Chem.39 (2000) 3791.

36 R.J. Francis, P.S. Halasyamani, D. O'Hare, Chem. Mater. 10 (1998) 3131.

37 S.M. Walker, P.S. Halasyamani, S. Allen, D. O'Hare, J. Am. Chem. Soc. 121 (1999) 10513.

38 C.L. Cahill, P.C. Burns, Inorg. Chem. 40 (2001) 1347.

39 P.S. Halasyamani, S.M. Walker, D. O'Hare, J. Am. Chem. Soc. 121 (1999) 7415.

40 A.M. Chippindale, R.L. Walton, J. Chem. Soc. Chem. Commun. (1994) 2453.

41 A.M. Chippindale, A.R. Cowley, R.L. Walton, J. Mater. Chem. 6 (1996) 611.

42 J.C. Trombe, P. Thomas, C. Brouca - Cabarrecq, Solid State Sciences 3 (2001) 309.

43 Z. Bircsak, W.T.A. Harrison, Acta Crystallogr. C54 (1998) 1383.

44 F. Fourcade - Cavillou, J.C. Trombe, Solid State Sciences 4 (2002) 1199

45 M. Saadi, Thesis, Lille, 1994. 
46 SAINT Plus Version 6.22, Bruker Analytical X - ray Systems, Madison, WI, 2001.

47 SADABS Version 2.03: Bruker Analytical X - ray Systems, Madison, WI, 2001.

48 A. Altomare, G. Cascaro, G. Giacovazzo, A. Guargliardi, M.C. Burla, G. Polidori, M. Gamalli, J. Appl. Crystallogr. 27 (1994) 135

49 V. Petricek, M. Dusek, JANA2000, Institute of Physics, Praha, Czech Republic, 2005 .

50 C. Frondel, D. Riska, J. W. Frondel, U. S. Geol. Surv. Bull. 1036 - G (1956) 91.

51 M. Saadi, Thesis, El Jadida, Morocco, 2001.

52 F. Cesbron, Bull. Soc. Fr. Minéral. Cristallogr. 93 (1973) 320.

53 P.C. Burns, R.C. Ewing, F.C. Hawthorne, Can. Miner. 35 (1997) 1551.

54 F. Abraham, C. Dion, M. Saadi, J. Mater Chem. 3(5) (1993) 459.

55 R. Enjalbert, J. Galy, Acta Crystallogr. C42 (1986) 1467.

56 N. E. Brese, M. O'Keeffe, Acta Crystallogr. B47 (1991) 192.

57 M. Gasperin, Acta Crystallogr. C43 (1987) 404.

58 A. J. Locock, S. Skanthakumar, P. C. Burns, L. Soderholm, Chem. Mater. 16 (2004) 1384.

59 P.C. Burns, M.L. Miller and R.C. Ewing, Can. Mineral. 34 (1996) 845, P.C. Burns, Can. Mineral. 43 (2005) 1839.

60 A.J. Locock and P.C. Burns, J. Solid State Chem. 176 (2003) 18.

61 R. D. Shannon, Acta Crystallogr. A32 (1976) 751.

62 A. A. Khan, W. Baur, Acta Crystallogr. B28 (1972) 683.

63 N. Tancret, S. Obbade, F. Abraham, Eur. J. Solid State.Inog. Chem. 32 (1995) 195; A.M. Chippindale, P. J. Dickens, G. J. Flynn, G. P. Stuttard, J. Mater. Chem. 5 (1995) 141. 


\section{Figure caption.}

Fig. 1: The structure building unit block formed of two edge-shared $\mathrm{UO}_{7}$ pentagonal bipyramids and two edge-shared $\mathrm{VO}_{5}$ square pyramids further connected by edge with the labelled scheme for a) compounds $\mathbf{1}$ and $\mathbf{5}$, b) compound 2.

Fig. 2: The francevillite anion topology (a) and the uranyl vanadate layers in carnotite - type compounds: (b) $u d / d u$ isomer layers $\mathrm{P}$ in $\mathrm{M}^{+}-, \mathrm{M}^{2+}$ - or 1,3 - diaminopropane - containing compounds; (c) ud/ud isomer layers $\mathrm{P}^{\prime}$ in ethylenediamine - and 1,4 - dimethylpiperazine containing compounds.

Fig. 3: Stacking of the $\mathrm{P}$ and $\mathrm{P}$ ' layers in carnotite type compounds containing monovalent ions and 1 (a), divalent inorganic ions and 3 (b), 1,4 - dimethylpiperazine 5 (c) and ethylenediamine (not localized from $\mathrm{X}$ - ray powder diffraction data) 6 (d).

Fig. 4: The uranophane type uranyl vanadate sheet in the structure of 4 and 6.

Fig. 5: Localisation of the ammonium cation above the $u d / d u$ geometrical isomer layer in 1 (a), dimethylpiperazine ions above the $u d / u d$ geometrical isomer layer in 5 (b), piperazine and dabco above the uranophane-type layer in $\mathbf{4}$ and 6, (c) and (d), respectively.

Fig. 6: Variation of the interlayer distance versus the ionic radii of 8-coordinated monovalent ion $\mathrm{A}_{2}\left[\left(\mathrm{UO}_{2}\right)_{2} \mathrm{~V}_{2} \mathrm{O}_{8}\right]$ compounds built on carnotite-type layers.

Fig. 7: One orientation of the pseudo-trigonal $\left[\mathrm{H}_{2} \mathrm{dabco}\right]^{2+}$ cations showing the disorder presented by the $\mathrm{C}(3)-\mathrm{C}(4)$ group. The general positions of $\mathrm{C}(1), \mathrm{C}(2)$ and $\mathrm{N}(1)$ atoms are half occupied. 

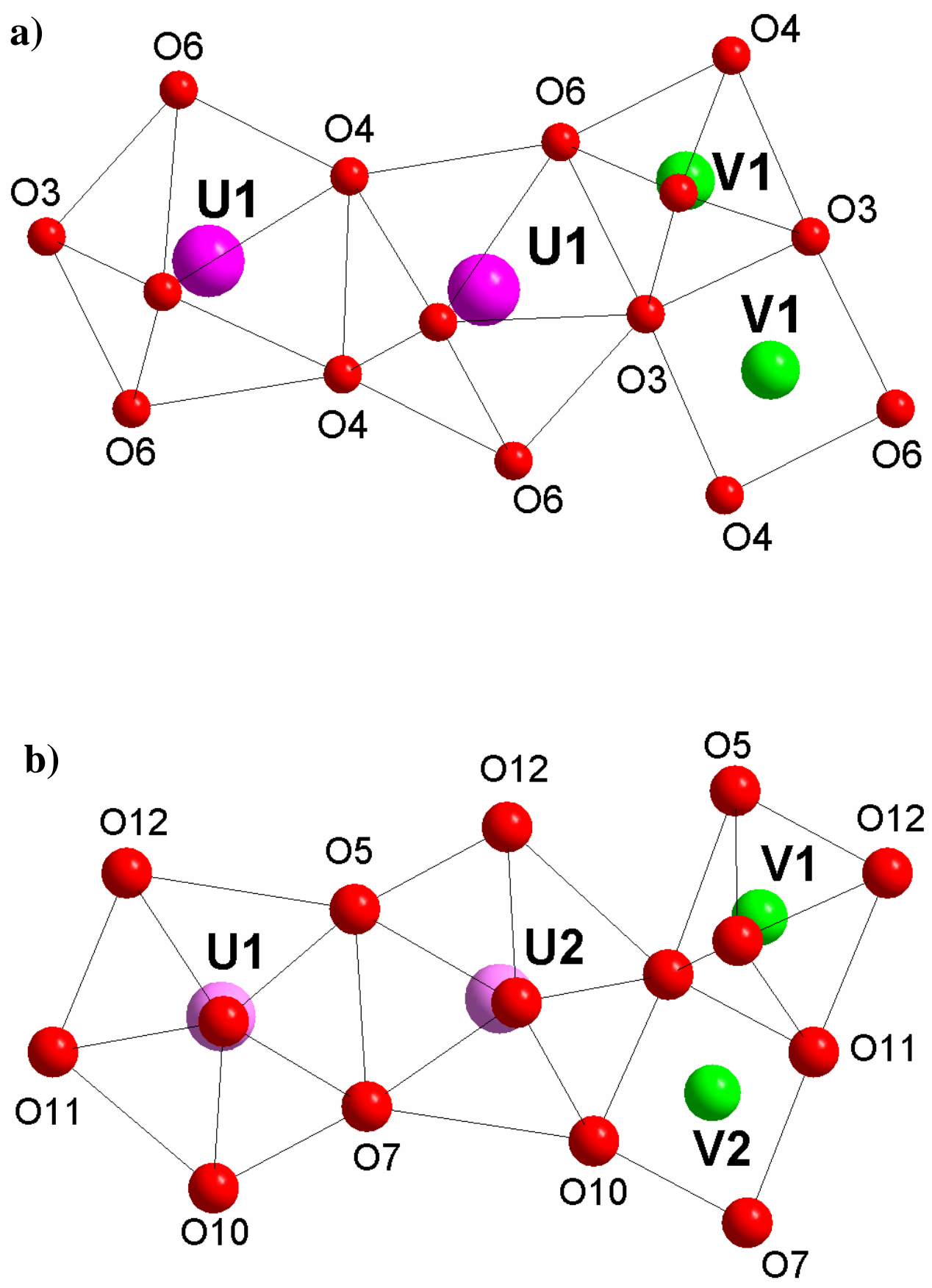


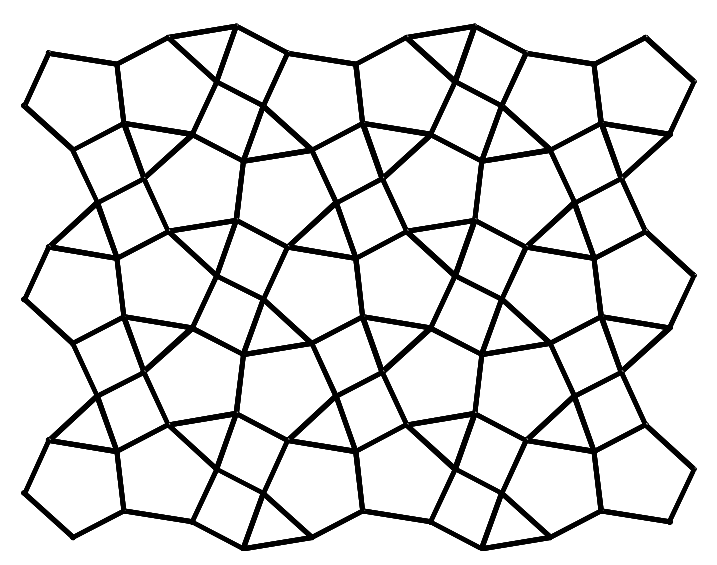

(a)

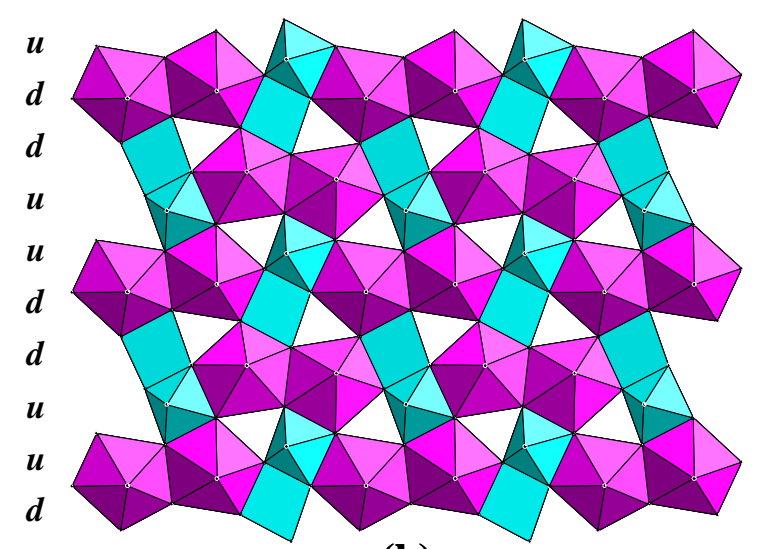

(b)

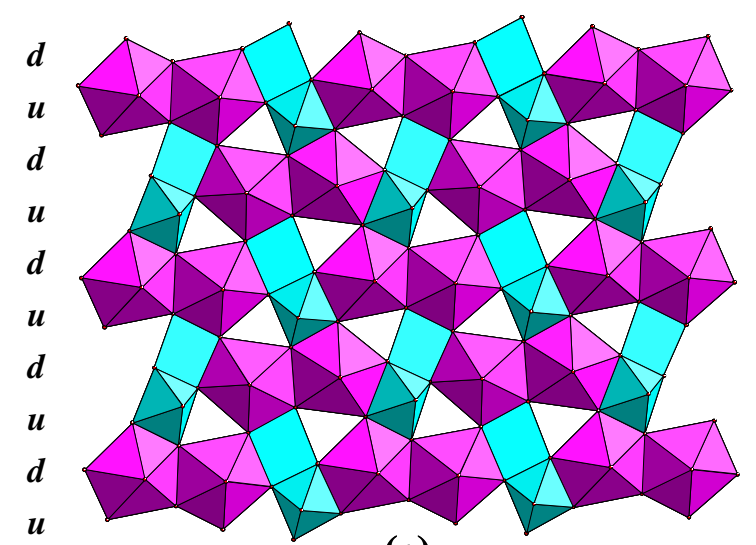

(c) 


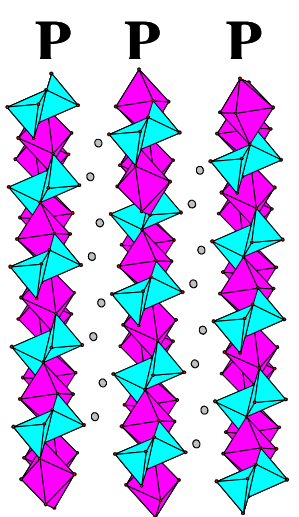

(a)

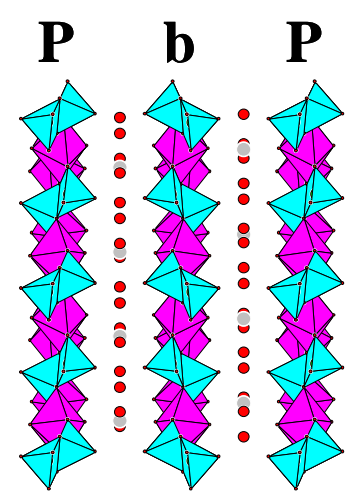

(b)

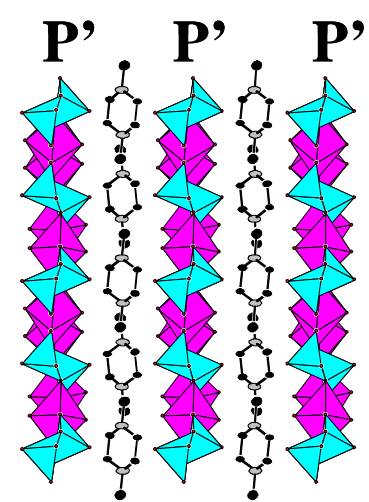

(c)

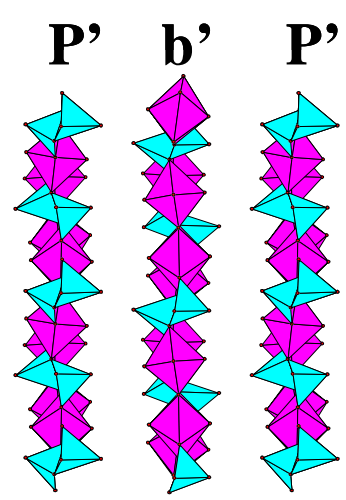

(d) 


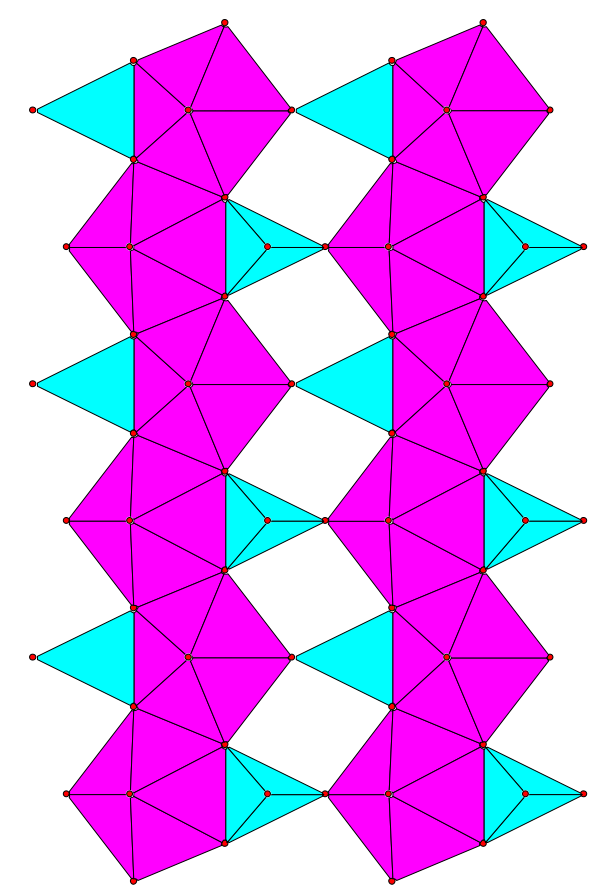




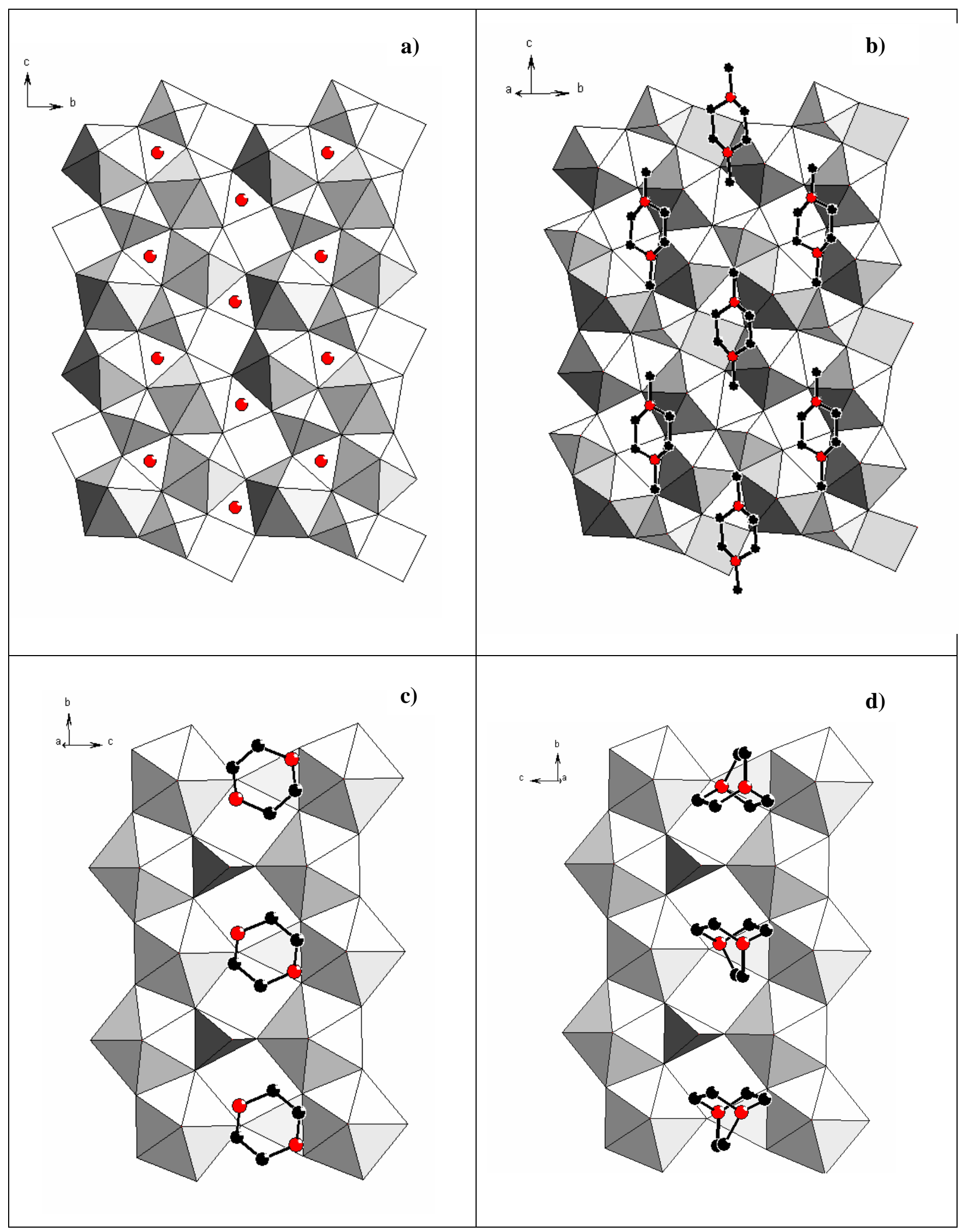




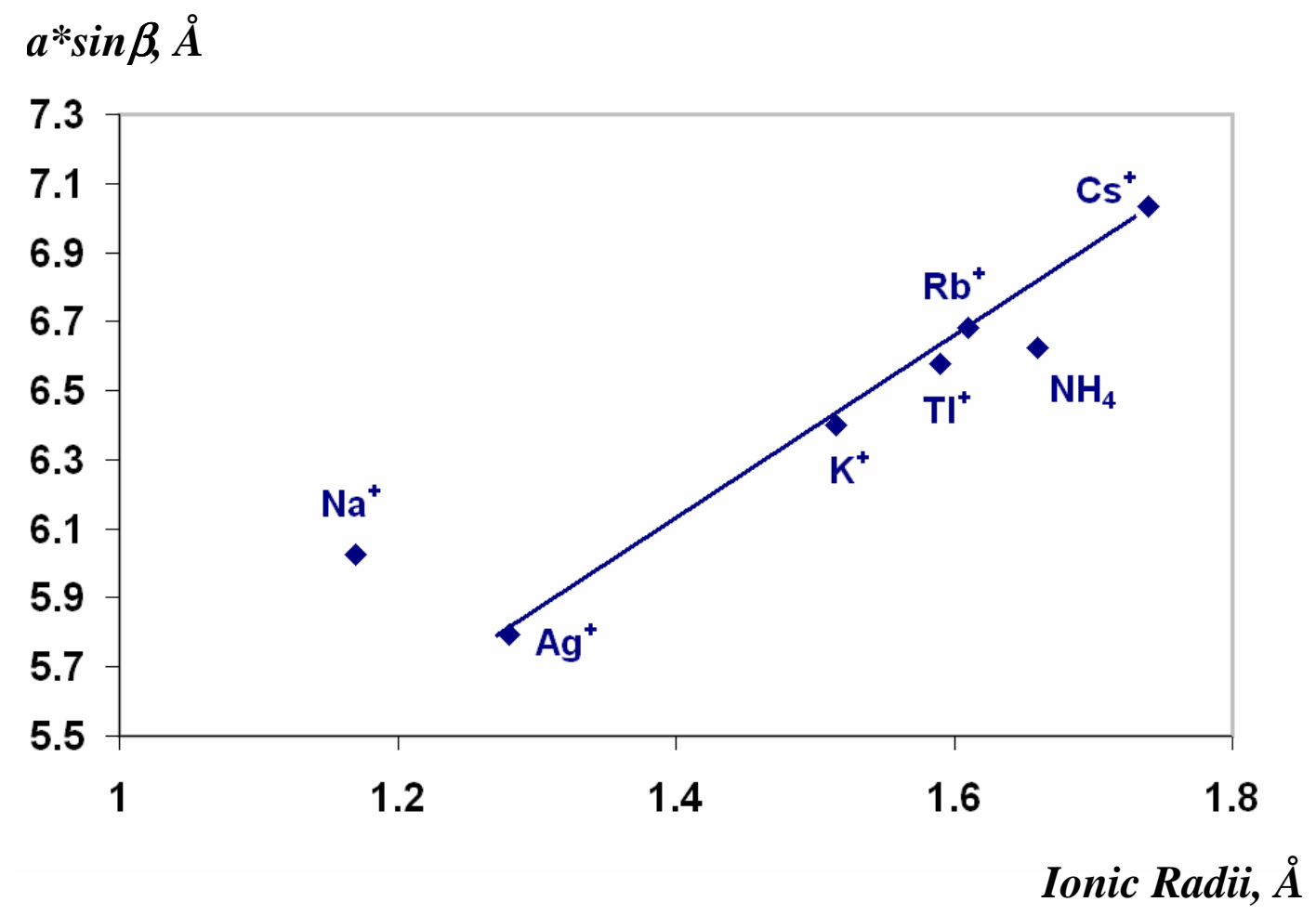




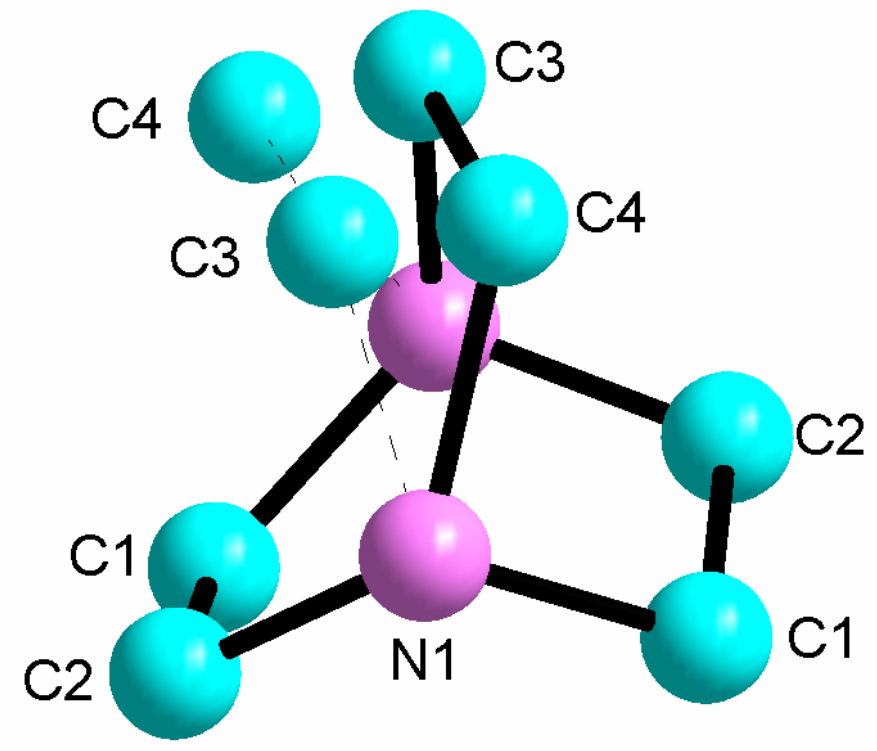

